\title{
Improving the Role of Ombudsman as a Monitoring Institution of Public Organization in Indonesia
}

\author{
Budi Ispriyarso $^{1}$, Siti Malikhatun Badriyah ${ }^{2}$ \\ \{budiispriyarso@live.undip.ac.id ${ }^{1}$ \} \\ Universitas Diponegoro, Indonesia ${ }^{1,2}$
}

\begin{abstract}
The Ombudsman in Indonesia is regulated based on Law Number 37 of 2008 concerning the Republic of Indonesia's Ombudsman. One of the Ombudsman's legal product results in public scrutiny is a recommendation. Based on the existing facts, 60 percent of the Ombudsman's recommendations were not complied with by the reported institution. The purpose of this study is to strengthen the function and authority of the RI ombudsman as a public service supervisory agency. The problems are: 1). What is the Ombudsman's role as a public administration supervisor in Indonesia; 2). How to increase the Ombudsman's role as a supervisor in delivering public services. The research method used in this research is normative juridical emphasizing secondary data. The results showed that the Ombudsman role was not optimal as a supervisory agency for implementing public services, especially concerning the recommendations issued, many of which were not obeyed by the reported institutions. The Ombudsman in the future must be strengthened by giving the Ombudsman the authority to directly apply administrative sanctions on the reported institution. The Ombudsman does not only provide recommendations, but so that the Ombudsman becomes an adjudicator. Therefore, it is necessary to immediately issue a Presidential Regulation that further regulates this matter.
\end{abstract}

Keywords: Ombudsman, Public Service, Recommendation, Supervisory Agency

\section{Introduction}

Indonesia is a welfare state. It can be seen from the goal of establishing the state, namely creating the welfare for all Indonesian people. The concept of the Welfare State is contained in the Paragraph IV of the Preamble to the UUD NRI 1945. It affirms that the objective of the formation of the Indonesian Government is to protect the entire Indonesian nation and all the blood of Indonesia, promote public welfare and educate the nation's life. Concerning the welfare state, in the body of the Constitution of the Republic of Indonesia (after this referred to as UUD NRI 1945), it also reflects that the Indonesian state is a Welfare State. Some of these articles, among others, are Article 27 (citizens have the right to decent work and education), Article 31 (educational services), Article 33 (natural wealth is used for the most excellent welfare of the people), Article 34 (the poor and neglected children are cared for by the state). Indonesia has 14 articles on welfare in the UUD NRI 1945, more than other countries (Norway, America, Japan). Norway only includes 3 articles in its constitution (Article 110, 110a and Article 110b); in Japan, there is only 1 article in its constitution related to welfare [1]. However, these countries have a better welfare level than Indonesia. In the Indonesian state, the reality is that matters related to welfare have not been fully achieved as regulated in its constitution. 
In the Welfare State, this is reflected, among others, by the existence of services provided by the state to its people, for example, in cheap/free education, cheap housing, affordable public transportation, health services, and soon.

Public service is one of the crucial public administration goals, including the implementation of public services, public affairs (public interests and public needs), and distribution of public service equally [2][3][4].

In connection with these public services, in Indonesia, it is regulated in the Act No. 25 the Year 2009 concerning Public Services (the Act on Public Services). Public services in Indonesia are still perceived as poor, this can be seen, among others, the low quality of public services organized by government officials and state, high levels of abuse of authority in the form of corruption, collusion and nepotism, long bureaucracy and/or unclear service standards [5][6][7]. Based on an international transparency survey, namely the Global Corruption Barometer, as many as $30 \%$ of Indonesians who use public services have to pay bribes [8].

The Ombudsman carries out supervision of the delivery of public services in Indonesia. The existence of the Ombudsman in Indonesia is regulated through the Act No. 37 the Year 2008 concerning the Republic of Indonesian Ombudsman. This institution is an independent institution with authority to issue recommendations regarding completing reports to be executed and/or followed up to improve the quality of good government administration.

Many recommendations from the Ombudsman were not followed or implemented by the reported agency in practice. As expressed by Mahfud MD (Coordinating Minister for Politics, Law and National Security Affairs) [9], the Ombudsman has become the supervisor of public services in Indonesia. However, it was found that there are still many recommendations from the Ombudsman that have not been implemented by government agencies/institutions.

Based on the description above, it can be seen that the role of the Ombudsman as a public service supervisory agency in Indonesia is still not as expected, especially from the many recommendations that have not been complied with by the reported agency. The problems that arise are as follows:

a. What is the role of the Ombudsman as a supervisor in the implementation of public services in Indonesia?

b. How to increase the Ombudsman's role as a supervisor in delivering public services?

\section{Research Methods}

The approach method used in this study is a normative (non-doctrinal) method, namely research whose main data comes from secondary data (data obtained from literature review materials which include primary legal material, secondary legal material, and tertiary legal materials), books/literature, scientific journals, research results, articles, etc. related to the ombudsman problem. 


\section{Results and Discussion}

\subsection{The Ombudsman's role as a Supervisor in the Implementation of Public Services in Indonesia}

In Indonesia, supervision of the implementation of public services consists of external and internal supervision. It is stated in Article 35 of the Act on Public Services 2009. External supervision is hold by community supervision, supervision by the Ombudsman, and supervision by the House of Representatives, the Provincial Regional People's Representative Council (DPRD I), Regency/City Regional People's Representative Council (DPRD II). Internal supervision is hold by supervision by direct superiors following statutory regulations; and by functional supervisors.

According to the Act Number 37 the Year 2008 (Article 1), the Ombudsman is included in the external supervisory role and is independent. The Ombudsman of the Republic of Indonesia, starting now referred to as the Ombudsman, is a state institution with the authority to supervise the implementation of public services both organized by government officials and state. Including those organized by State-Owned Enterprises, Region-Owned Enterprises, and StateOwned Legal Entities as well as private entities or an individual who is assigned the task of administering certain public services whose funds partially or wholly originate from the state revenue and expenditure budget and/or regional revenue and expenditure budget.

The legal basis for the Ombudsman in Indonesia is the Act Number 37 the Year 2008. The rationale for the need to form an Ombudsman in Indonesia is to improve further the protection of people's rights from State administrators who are considered detrimental in providing public services to them. People who feel aggrieved by state officials can complain to an independent institution known as the Ombudsman. The duties of the Ombudsman include examining reports of suspected maladministration in public services, examining the substance of the report, following up on reports that fall within the scope of the Ombudsman's authority, coordinating and cooperating with state agencies or other government agencies as well as civil society organizations and individuals, etc.

Maladministration is behavior or acts against the law, exceeds authority, uses authority for purposes other than those of the said authority, including negligence or neglect of legal obligations in the provision of public services carried out by the administration of state and government which cause material and/or immaterial harm to the community and individuals [10]. In comparison, the ombudsman function is the Ombudsman. His function is to supervise the implementation of Public Services organized by public service providers (central and local governments, State/Regional Owned Enterprises, and private bodies or individuals assigned the task of carrying out certain public services). Public service is an activity or a series of activities to fulfill services following laws and regulations for every citizen and resident for goods, services, and/or administrative services provided by public service providers (Article 1 number 1 of Law Number 25 the Year 2009).

Antonius Sujata [11] argues that the Ombudsman generally has the following roles: 1). Creating general principles of good governance; 2). Upholding democracy by providing the best possible service to the community; 3). Protecting Human Rights; 4). Eradicating Corruption. The four roles of the Ombudsman as stipulated in the Ombudsman Regulation No. 4 the Year 2010 concerning Organization and Work Procedures in the Ombudsman, among others, are receiving consultation and verification, conducting field investigations, following up on reports, monitoring the process of recommendations, mediation, and decisions special gambling. The 
way the Ombudsman works includes how and in what way the Ombudsman receives public reports, the administrative research process, the process of compiling a resume, compiling requests for clarification, and issuing recommendations from the Ombudsman [12]. The definition of recommendation (Ombudsman) based on Article 1 (7) of the Act Number 37 the Year 2008 is a conclusion, opinion, and suggestion based on the results of the Ombudsman investigation to the reported superior to be implemented and/or followed up in order to improve the government administrations quality. Recommendations are the last way to resolve maladministration; the Ombudsman still has several non-litigation methods, namely conciliation, mediation, particular adjudication, and advice [13].

\subsection{Increasing the Role of the Ombudsman as a Supervisor in the Implementation of Public Services}

Based on the description above, in brief, based on the duties and functions of the Ombudsman, it can be said that the role of the Ombudsman is vital in the implementation of public services in Indonesia. Ombudsman is in the context of overseeing the implementation of public services to make state and government apparatus that is effective and efficient, honest, clean, open, and free from corruption, collusion, and nepotism.

The critical role of the Ombudsman in this public service, as expressed by the President of the Republic of Indonesia, Ombudsman has been helping to improve the public services' quality in Indonesia. Likewise, the deputy chairman of the Ombudsman, Lely Pelitasari Soebekty, that the role of the Ombudsman in completing reports by the Ombudsman does not all have to be resolved through recommendations, this is because reports can be completed before the Recommendation stage, namely through a corrective action scheme based on the Final Audit Result Report (LAHP).

Table 1. Number of public complaints Year (2014 to 2019)

\begin{tabular}{ccc}
\hline No. & Year & Number of Public Complaints \\
\hline 1 & 2014 & 5753 \\
2 & 2015 & 5694 \\
3 & 2016 & 7287 \\
4 & 2017 & 7503 \\
5 & 2018 & 7817 \\
6 & 2019 & 7258 \\
\hline \multicolumn{3}{c}{ Source: Ombudsman Annual Report 2020. }
\end{tabular}

Throughout 2020, the Indonesian Ombudsman has received public reports related to public services implementation totaling 7,204 reports. The reports consist of 6,522 regular reports, 559 Rapid Responses, and 123 are self-initiated investigations. From public reports based on allegations of maladministration, there are three categories of complaints mostly. Namely reports on protracted delays amounting to $31.57 \%$, deviation of procedures as much as $24.77 \%$, and not providing services as much as $24.39 \%$. Meanwhile, based on reporters' distribution, the highest number of reports was at the Head Office with 1,641 reports, North Sumatra with 319 reports, East Java with 307 reports, North Sulawesi with 273 reports, and South Kalimantan with 165 reports [14].

The Ombudsman's role in public service delivery supervision is vital to suppress/reduce maladministration. However, in reality, the Ombudsman, who, among other things, has a legal product in the form of a recommendation, is often not obeyed by the reported party. Many state 
officials who get recommendations from the Ombudsman do not follow up on the Ombudsman's recommendations [15]. The compliance of government agencies in implementing the Ombudsman's recommendations of the Republic of Indonesia is deficient. Over the past few years, only 40 percent of the Ombudsman's recommendations have been followed. The rest ignored these recommendations. In other words, 60 percent of the reported institutions did not comply with the Ombudsman's recommendation [16]. Compared with other countries, for example, Thailand, implementing the ombudsman recommendation is 90 percent. Australia has 99 percent the compliance level with the execution of the ombudsman recommendation, the compliance level with the execution of the ombudsman recommendation in Indonesia is still deficient.

The non-compliance with the Ombudsman's recommendation was partly since the Ombudsman's recommendation did not have a compulsion for the reported institution conducting maladministration. Sanctions for the reported institution that does not implement the Ombudsman's recommendation, the Ombudsman will publish the reported supervisor who does not implement the recommendation and submit a report to the House of Representatives President. Also, the reported party and the reported superior may be subject to administrative sanctions following the legislation's provisions. It is as regulated in the provisions of Article 38 of the Act 37/2008, which states that:

1. The Reported Party's superiors and the reported party must execute the Ombudsman's Recommendation.

2. The Reported Party's superior is obliged to submit a report to the related Ombudsman regarding the implementation of the Recommendation which has been carried out along with the results of the examination within no later than 60 (sixty) days from the date of receipt of the recommendation.

3. The Ombudsman can request information from the Reported Party and/or their supervisors and carry out field checks to ensure the Recommendation's implementation.

4. Suppose the Reported Party's supervisor and the reported party do not implement the Recommendation/only part of the Recommendation for reasons that the Ombudsman cannot accept. In that case, the Ombudsman can publish the Reported Party's superior who did not implement the Recommendation and submit a report to the President and the House of Representatives (DPR).

Furthermore, Article 39 of Law Number 37 of 2008 regulates the following administrative sanctions:

"The Reported Party's superiors and the Reported Party who violate the provisions referred to in Article 38 paragraph (1), paragraph (2), or paragraph (4) will be subject to sanctions of administrative in accordance with the provisions of laws and regulations".

Based on the description above, it can be seen that many ombudsman recommendations were not implemented by the reported agency, because the sanctions were not strong enough. The recommendation is only a suggestion or suggestion even though there are administrative sanctions. The Ombudsman's recommendation is not like a court decision which has executorial power. Sanctions for non-compliance with the Ombudsman's recommendations convey to superiors or the President and the DPR to follow up if they occur in the event that the Ombudsman's recommendations are not complied with and moral sanctions, namely the 
publication of the reported party and the reported supervisor, in addition to administrative sanctions regulated by legislation.

The aforementioned factors are the causes of the many ombudsman recommendations that were not implemented by the reported agency. Therefore, going forward, this Ombudsman must be strengthened so that the recommendations are implemented by the reported agency.

Strengthening the Ombudsman in the future can be done by giving the Ombudsman the authority to directly impose administrative sanctions on agencies that do not carry out their recommendations. Thus, it is hoped that the reported agency can comply with the recommendations issued by the Ombudsman. However, in granting the authority to give administrative sanctions, it must be noted that there is no overlap with other institutions.

The Ombudsman of the Republic of Indonesia must be given stronger authority, not only limited to issuing recommendations, but must also be an adjudicator. Although there is already an Ombudsman regulation No. 31 Year 2018 concerning Special Adjudication, but until now, since the issuance of the Public Service Law, there has been no presidential regulation regarding the provision of compensation payments. When a special adjudication decision by the Ombudsman states that the organizer has committed maladministration and is obliged to provide compensation, there is no legal basis. Therefore, it is necessary to issue a Presidential Decree as the legal basis.

\section{Conclusion}

The following can be concluded based on the description above: 1). The Ombudsman has a vital role as a supervisory agency for implementing public services in Indonesia. Its role can be seen from its duties, functions, and authorities. The Ombudsman role has helped improve the quality of public services in Indonesia. Many ombudspersons received reports of public complaints about administrative malls. The Ombudsman then follows up on the incoming reports, among others, by conducting administrative research processes, compiling resumes, compiling requests for clarification, and issuing recommendations from the Ombudsman. However, not all of the completion of the Ombudsman report has to be completed through a recommendation. The report can be completed before the Recommendation stage, namely through corrective action based on the Final Audit Result Report (LAHP). 2). The recommendations of the Indonesian Ombudsman, in practice, are often not complied with by the reported institutions; a number, 60 percent of the reported institutions do not comply with recommendations. It is because the recommendation of its binding strength is only a suggestion or recommendation, even though in its development it is equipped with administrative sanctions for the reported institution that does not implement the Ombudsman's recommendation. There are still many ombudsman recommendations that have not been implemented. Ombudsman's recommendation does not have forced power. Therefore, the Ombudsman must be strengthened by giving the Ombudsman the authority to directly impose sanctions (administrative sanctions) on the reported institution that does not implement the recommendations given. Thus, it is hoped that the reported institutions can comply with the recommendations.The Ombudsman of the Republic of Indonesia must be given stronger authority, not only limited to issuing recommendations, but must have become an adjudicator. Therefore, it is necessary to immediately issue a Presidential Regulation that further regulates this matter. 


\section{References}

[1] Prime Minister of Japan and His Cabinet, "The Constitution of Japan," Prime Minister of Japan and His Cabinet." http://publicofficialsfinancialdisclosure.worldbank.org/sites/fdl/files/assets/lawlibraryfiles\%2520/\%2520Norway_Constitution_1814_\%2520(as\%25\%252020amended)\%2520 _en.pdf (accessed Mar. 12, 2021).

[2] $\quad \bar{N}$. Hamilton-Hart, "Anti-corruption strategies in Indonesia," Bull. Indones. Econ. Stud., vol. 37, no. 1 , pp. 65-82, 2001.

[3] LGSP-USAID, Legislative Strengthening Team, Pengawasan DPRD terhadap Pelayanan Publik. Jakarta, 2009.

[4] L. C. Reif, The ombudsman, good governance, and the international human rights system, vol. 79. Leiden: Martinus Nijhoff Publishers, 2004.

[5] S. Sherlock, "Combating corruption in Indonesia? The ombudsman and the assets auditing commission," Bull. Indones. Econ. Stud., vol. 38, no. 3, pp. 367-383, 2002.

[6] A. A. R. Fernandes and J. Fresly, "Modeling of role of public leader, open government information and public service performance in Indonesia," J. Manag. Dev., vol. 36, no. 9, pp. 1160-1169, 2017.

[7] A. Imron Rizki, “Analisis Pelaksanaan Rekomendasi Ombudsman sebagai Instrumen Pengawas Kebijakan Publik," J. Al-Adalah, vol. 3, no. 1, pp. 46-55, 2018.

[8] V. Lidyana, "Sri Mulyani: 30\% Pengguna Layanan Publik Masih Harus Bayar Sogokan," DetikFinance, 2020. https://finance.detik.com/berita-ekonomi-bisnis/d-5290642/sri-mulyani-30pengguna-layanan-publik-masih-harus-bayar-sogokan.

[9] MD. Mahfud, "Mahfud: Banyak Rekomendasi Ombudsman RI Belum Dijalankan Pemerintah," Bisnis.com, 2021. https://kabar24.bisnis.com/read/20210208/15/1353741/mahfud-banyakrekomendasi-ombudsman-ri-belum-dijalankan-pemerintah.

[10] Y. Hasjimzoem, "Eksistensi Ombudsman Republik Indonesia," Fiat Justisia, vol. 8, no. 2, pp. 192-207, 2014.

[11] A. Sujata, Ombudsman Indonesia, Masa Lalu, Sekarang dan Masa Mendatang. Jakarta: Komisi Ombudsman Nasional, 2002.

[12] B. Masthuri, Mengenal Ombudsman Indonesia. Jakarta: Pradnya Paramita, 2005.

[13] A. Patulak and H. Giovanny, "Optimalisasi Peran Ombudsman Republik Indonesia dalam Mendukung Sustainable Development Goals Nomor 16 (Target 16.6),” J. Legis., pp. 269-286, 2020 .

[14] Ombudsman Republik Indonesia, “Ombudsman RI Luncurkan Laporan Tahunan 2020,” 2021. https://www.ombudsman.go.id/news/r/ombudsman-ri-luncurkan-laporan-tahunan-2020.

[15] A. Setiawan, "Politik Hukum: Memperkuat Ombudsman, Memperlemah Maladministrasi," waspada.co.id, 2019. https://waspada.co.id/2019/01/politik-hukum-memperkuat-ombudsmanmemperlemah-maladministrasi/.

[16] E. Widianto, "60 Persen Lembaga Tak Patuhi Rekomendasi ORI," Tempo.co, 2014. https://nasional.tempo.co/read/620196/60-persen-lembaga-tak-patuhi-rekomendasiori/full\&view=ok. 